\section{Effects of $11 \beta$-Hydroxysteroid Dehydrogenase Type 1 Enzyme in the Liver in Fructose Induced Metabolic Syndrome Rat Model}

\author{
NORSHALIZAH $M^{1}$, ZAR CHI T1 ${ }^{1}$ FARIHAH S ${ }^{2}$ \\ ${ }^{1}$ Discipline of Anatomy, Basic Medical Science Cluster, Faculty of Medicine, Universiti \\ Teknologi MARA, Sungai Buloh Campus, Jalan Hospital, 47000 Sungai Buloh, Selangor, \\ Malaysia. \\ ${ }^{2}$ Department of Anatomy, Faculty of Medicine, Universiti Kebangsaan Malaysia Medical \\ Centre, Jalan Yaacob Latif, Bandar Tun Razak, 56000 Cheras, Kuala Lumpur, Malaysia.
}

\begin{abstract}
ABSTRAK
Peningkatan ekspresi dan aktiviti enzim 11ß-hidroksisteroid dehidrogenase jenis 1 (11ß-HSD1) di dalam sel adiposit matang menyebabkan obesiti dan sindrom metabolik. Fruktos dalam air minuman telah terbukti boleh menyebabkan sindrom metabolik pada tikus Wistar jantan. Oleh itu, kajian ini dilakukan untuk melihat kesan ke atas ekspresi dan aktiviti enzim 11ß-HSD1 di dalam hati model tikus sindrom metabolik yang dirangsang dengan air minuman fruktos. Sebanyak 12 ekor tikus Wistar jantan dibahagikan secara rawak kepada dua kumpulan: kumpulan kawalan, $C(n=6)$ dan kumpulan yang diberi minuman fruktos 20\%, F2O (n=6). Pemberian makanan dan air minuman selama lapan minggu secara ad libitum. Di akhir kajian, pengukuran ekspresi enzim 11ß-HSD1 di dalam hati dilakukan dengan menggunakan teknik pewarnaan imunohistokimia. Skor diberikan berdasarkan intensiti pewarnaan granul di dalam sitoplasma hepatosit menggunakan teknik 'double-blinded'. Manakala, aktiviti enzim 11ß-HSD1 diukur menggunakan teknik ELISA. Selepas lapan minggu pengambilan air minuman fruktos, kumpulan F2O menunjukkan peningkatan dalam ekspresi dan aktiviti enzim 11ß-HSD1 di dalam hati. Data yang diperolehi menunjukkan bahawa enzim 11ß-HSD1 di dalam hati mungkin memainkan peranan dalam pembentukan sindrom metabolik dan komplikasinya pada tikus Wistar jantan.
\end{abstract}

Kata kunci: 11ß-hidroksisteroid dehidrogenase, fruktos, sindrom metabolik, tikus Wistar

Address for correspondence and reprint requests: Farihah Suhaimi, Department of Anatomy, Faculty of Medicine, Universiti Kebangsaan Malaysia Medical Centre, Jalan Yaacob Latif, Bandar Tun Razak, 56000 Cheras, Kuala Lumpur, Malaysia. Tel: +603 91458639/8605 Fax: +60391458607 E-mail: farihah@ppukm. ukm.edu.my/farihah_suhaimi@yahoo.com 


\section{ABSTRACT}

Excessive expression and activity of $11 \beta$-hydroxysteroid dehydrogenase enzyme type $1(11 \beta-H S D 1)$ enzyme in mature adipocyte leads to obesity and metabolic syndrome. Fructose in drinking water was proven to induce metabolic syndrome in male Wistar rat. Hence, the aim of the study was to assess the effects of expression and activity of $11 \beta-H S D 1$ enzyme in the liver in an established metabolic syndrome rat model induced by fructose drinking water. Twelve male Wistar rats were randomly divided into two groups: Control group, $\mathrm{C}(\mathrm{n}=6)$ and Fructose drinking water $20 \%$, F20 $(n=6)$. The food and fluid intake were given as ad libitum for eight weeks. At the end of the experiment, the expression of $11 \beta-H S D 1$ enzyme in the liver was measured by immunohistochemical staining method. The score was given according to the intensity of the staining of the granules in the hepatocyte cytoplasm which was measured using double-blinded method. Meanwhile, the activity of $11 \beta-H S D 1$ enzyme in the liver was measured using ELISA technique. Following eight weeks of consumption of fructose drinking water, the F20 group showed an increased in both expression and activity of $11 \beta-H S D 1$ in the liver. The obtained data clearly suggest that $11 \beta-H S D 1$ enzymes in the liver may play a role in the development of metabolic syndrome and its complications in male Wistar rat.

Keywords: $11 \beta$-hydroxysteroid dehydrogenase, fructose, metabolic syndrome, Wistar rat

\section{INTRODUCTION}

Metabolic syndrome (MetS) is a constellation of medical conditions consisting of central obesity, hyperglycemia, hypertension, and dyslipidemia. Based on a joint interim statement, a person is diagnosed to have MetS with at least three of these conditions. The prevalence suffered by MetS is growing worldwide. It is associated with the increased morbidity and mortality following its complications which include heart disease (Kim et al. 2010). Previous studies suggested that consumption of fructose leads to the development of MetS (Elliott et al. 2002).

Though MetS may share the same features as Cushing's disease, there are striking resemblances between these two conditions. In contrast to Cushing's disease, plasma cortisol tends to be normal or lower in MetS. Nevertheless, rodent obesity models showed glucocorticoid plays an important role in the metabolic disease. The glucocorticoid reactivation is mediated by the enzyme known as $11 \beta$-hydroxysteroid dehydrogenase (11 $\beta-H S D)$. Amelung and his colleagues discovered the $11 \beta$-hydroxysteroid dehydrogenase enzyme (11 $\beta$-HSD) in 1953 (Morton \& Seckl 2008). This enzyme converts the inactive glucocorticoid hormone to active glucocorticoid hormone. Cortisone is an inactive form of glucocorticoid in human meanwhile 
11-dehydrocorticosterone in rodents. Cortisol and corticosterone is the active form of glucocorticoid in human and rodents respectively (Cooper \& Stewart 2009). The activity of $11 \beta-H S D$ in cell and tissue was first explained by Monder and White in 1993 (Seckl et al. 2004). In 1980, Monder observed the activity of this enzyme in the liver was involved in the process of conversion of cortisone to cortisol by $11 \beta$-reductase (11ß-OR) as well as conversion of cortisone to cortisol by $11 \beta$-dehydrogenase $(11 \beta$ $D H)$. Apart from liver, this enzyme was also found in placenta (Popovici et al. 2006) and kidney (Schnackenberg et al. 2013).

There are two isozymes of $11 \beta-H S D$ which are $11 \beta-H S D$ type 1 (11ß-HSD1) and $11 \beta-H S D$ type 2 $(11 \beta-H S D 2)$. Both these enzymes are involved in the interconversion of active glucocorticoid to inactive glucocorticoid. Glucocorticoid hormones involved in stress adaptation, metabolism regulation and response to inflammation (Opperman 2006). The differences between these two isozymes are the co-factors, affinity and reaction of conversion (Draper \& Stewart 2005). The 11 $\beta-H S D 1$ enzyme was discovered earlier than that of $11 \beta$-HSD2 enzyme (Seckl et al. 2004). This enzyme plays an important role in the liver and it is also involved in the development of obesity (Masuzaki et al. 2001), dyslipidemia (Cooper \& Stewart 2009) and hyperglycemia (Andrews \& Walker 1999). The 11ß-HSD1 enzyme is widely distributed and dependent on nicotinamide adenine dinucleotide phosphate (NADPH) as a cofactor. This enzyme has bi-directional action which acts as reductase (11 $\beta-O R)$ and dehydrogenase (11 $\beta-D H)$ (Opperman 2006). However, the function as $11 \beta$ $\mathrm{OR}$ is more dominant compared to $11 \beta-\mathrm{DH}$. The $11 \beta-\mathrm{HSD} 1$ is widely expressed in human (Ricketts et al. 1998) and rodents (Moisan et al. 1990) including the liver (Bellemare et al. 2006), adipose tissue (Bujalska et al. 1997), lungs (Hundertmark et al. 1993), skeletal muscle, heart muscle and smooth muscle (Walker et al. 1991), anterior pituitary gland and brain (Moisan et al. 1990) and adrenal cortex (Shimojo et al. 1996). All these sites have glucocorticoid receptors except the heart and hippocampus (Whorwood et al. 1992).

Research studies showed the expression of $11 \beta-H S D 1$ enzyme was mostly around the central vein and reduced radially (Brereton et al. 2001). The presence of expression of $11 \beta-H S D 1$ enzyme on the adipose tissue and liver explained the pathogenesis of development of adiposity, carbohydrate metabolism and insulin sensitivity (Masuzaki et al. 2001). The development of central obesity was related to the $11 \beta-H S D 1$ enzyme as shown by its expression which was higher in visceral adipose tissue than in subcutaneous adipose tissue (Bujalska et al. 1997). The activity of this enzyme induces the differentiation of pre-adipocyte to adipocyte by glucocorticoid hormone thus, leading to the development of central obesity (Cooper \& Stewart 2009). Another research has showed that excessive expression of 11ß-HSD1 enzyme in mature adipocyte leading to the development of metabolic syndrome which presented with central 
obesity, dyslipidemia and insulin sensitivity (Masuzaki et al. 2001).

To the best of our knowledge, there are limited studies on the expression and activity of $11 \beta-H S D 1$ enzyme in the liver in MetS rat model following consumption of fructose drinking water. Therefore, the results of this study may contribute opportunities for development of therapeutic interventions through 11ß-HSD1 inhibitor in the MetS area.

\section{MATERIALS AND METHODS}

\section{PREPARATION OF FRUCTOSE IN DRINKING WATER}

Pure fructose $>99 \%$ (Syarikat Systerm Malaysia) was used. The preparation of fructose drinking water (FDW) was done fresh every alternate day (SánchezLozada et al. 2007) and based on weight/volume formula (Shahraki et al. 2011). To prepare fructose $20 \%$ drinking water, $20 \mathrm{gm}$ of fructose was diluted in $100 \mathrm{~mL}$ of tap water. The bottles were then covered with aluminium foil to prevent fermentation (Abdulla et al. 2011). The FDW was given daily for eight weeks as ad libitum.

\section{ANIMAL PREPARATION}

All procedures were carried out in accordance with the institutional guidelines for animal research of the Universiti Kebangsaan Malaysia (UKMAECFP/ANAT/2012/FARIHAH/18JULY/453-JULY-2012-AUGUST-2013). Twelve male Wistar rats weighing between 200 and 300g were housed individually in a temperature controlled room $\left(24^{\circ} \mathrm{C}\right)$ with adequate ventilation and illuminated for 12 hrs daily (lights on from 0700 to 1900) with free access to standard rat chow (Gold Coin, Klang, Selangor, Malaysia) and tap water ad libitum. The rats were acclimatised for 1 week. The rats were randomly divided into two groups. Each group comprised six rats. The F20 group was given $20 \%$ fructose in drinking water while the Control group (C) received only tap water.

\section{EXPERIMENTAL PROTOCOL}

After eight weeks, the rats were sacrificed by diethyl ether inhalation (Ahmad et al. 2011). The liver of each rat was sampled into 1-mm cubes and fixed immediately in $10 \%$ formalin for $48 \mathrm{hrs}$ to measure the expression of the enzyme by using the immunohistochemical (IHC) staining. The liver samples were sectioned into approximately $1 \mathrm{gm}$ weight and was immediately covered with aluminium foil and kept in the refrigerator at $-70^{\circ} \mathrm{C}$ for measurement of the activity of the $11 \beta-H S D$.

\section{EXPRESSION OF 11ß-HSD1 ENZYME IN LIVER}

The immunohistochemical staining was performed with LSAB-2 HRP system. After fixation with formalin $10 \%$ and processed, the liver samples were sectioned at $5 \mu \mathrm{m}$ and placed on a silanized glass slide and kept dry for $24 \mathrm{hrs}$. Then, the liver tissues on the slides underwent dewaxing with xylene and rehydrated with series of alcohol to water. The antigen was retrieved by placing the slides in the antigen retrieval 
solutions. The endogenous peroxidase activity was blocked with peroxidase blocking solution containing $\mathrm{H}_{2} \mathrm{O}_{2}$. The sections were then incubated with primary antibody. To abolish cross-reactivity, the biotinylated LINK was placed on the sections. Then, the sections were incubated with streptavidin conjugated with horseradish peroxidase (streptavidinHRP) and followed by incubation with substrate chromogen solution. Finally, the sections were counterstained with Mayer's Hematoxylin and dehydrated with series of alcohol followed by dewaxed with xylene. The slides were then mounted with DPX and viewed under light microscope.

The measurements of the expression of the enzymes were measured qualitatively under light microscope under magnification x20. The immunopositive cells were observed around the central vein. The score was given according to the intensity of the staining of the granules in the hepatocyte cytoplasm. Score 0 was given if there was no staining, score 1 for weak intensity staining followed by score 2 with mild intensity staining and final score 3 with the highest intensity of the staining of the granules. The scoring was done using double-blinded method (Haque et al. 2006).

\section{ACTIVITY OF 11ß-HSD1 ENZYME IN LIVER}

The liver samples were first kept cooled under room temperature. The sample was then put in the $10 \mathrm{~mL}$ test tube with $5 \mathrm{ml}$ of phosphate buffer solutions (PBS) added. The homogenization process was done in ice. The samples were then centrifuged at $1000 \mathrm{rpm}$ at $4^{\circ} \mathrm{C}$ for 10 mins. The top layer of the solutions was taken and placed in appendorf tube for further analysis.

The measurement of the activity of $11 \beta-H S D 1$ in the liver was performed using the ELISA kit. All ELISA kit components and samples were taken out from refrigerator and kept under room temperature just before used. The procedure were done according to the company standard procedure. For the assay procedure, determination of diluted standard wells, blank and samples were done. Wells with standard, blank and samples were added with $100 \mu \mathrm{l}$ of dilution. Then, removal of water was done following two hours of incubation at $37^{\circ} \mathrm{C}$. Each well was added with $100 \mu$ l Detection Reagent ' $A$ ' working solution. Again, incubation of the kit was done for $1 \mathrm{hr}$ at $37^{\circ} \mathrm{C}$. Following incubation, $350 \mu \mathrm{l}$ wash solution were used to wash the kit for 3 times. The kit was keep for incubation for 30 mins at $37^{\circ} \mathrm{C}$ following adding the $100 \mu$ of Detection Reagent B working solution to each well. Then it was washed for 5 times. Subsequently,each well was added with $90 \mu \mathrm{l}$ of Substrate Solution and followed by incubation for 20 mins at $37^{\circ} \mathrm{C}$. Then, each well was added with $50 \mu$ l of Stop Solution.

Finally, the reading of the enzymes activity were done by using spectrophotometry technique at 450 $\mathrm{nm}$ wave on microplate reader. The values of optic density (O.D) were taken as a value of the activity of the enzyme. 


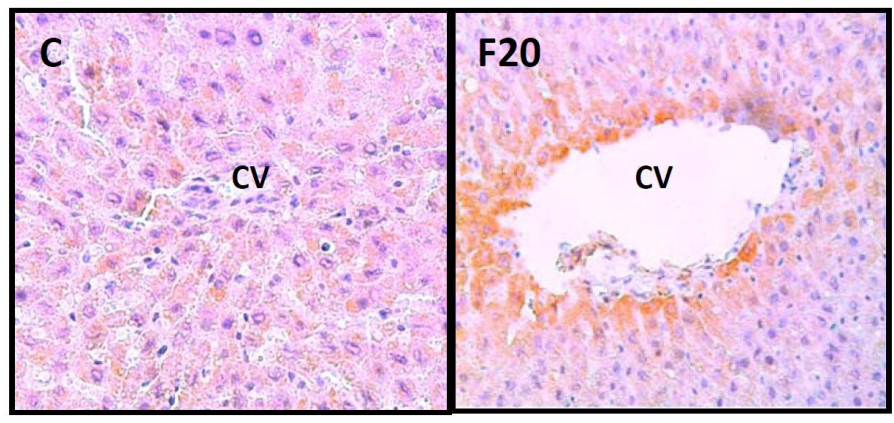

Figure 1: Immunohistochemical of liver to visualize the expression of $11 \beta-H S D 1$ enzyme. The granules of $11 \beta-H S D 1$ enzyme in the hepatocyte cytoplasm were stained brown by chromogen substrate DAB. The staining was highest around the central vein and reduced radially.

\section{STATISTICAL ANALYSIS}

All data were tested for normal distribution and presented as Mean standard error of mean (SEM). The comparisons between groups were analysed by a one-way Analysis of Variance (ANOVA) followed by Tukey test for multiple group comparisons. The level of significance was taken as $p<0.05$. All statistical analysis was conducted using SPSS version 20 software.

\section{RESULTS}

\section{EXPRESSION OF 11ß-HSD1 ENZYME IN LIVER}

The immunohistochemical staining to measure the expression of the enzyme was shown in Figure 1. The granules of $11 \beta-H S D 1$ in the hepatocytes cytoplasm were stained brown which was highest around the central vein and reduced radially in all the three groups. In the group that was given fructose in drinking water showed greater intensity of discoloration around the central vein as compared to the $C$ group. The statistical analysis showed that the scoring was significantly higher in F20 compared to $\mathrm{C}$ group (Figure 2A).

\section{ACTIVITY OF 11 $\beta$-HSD1 ENZYME IN LIVER}

Following consumption of fructose in drinking water for eight weeks, the activity of $11 \beta-H S D 1$ enzyme in the liver was significantly increased in F20 group compared to $\mathrm{C}$ group (Figure $2 \mathrm{~B}$ ).

\section{DISCUSSION}

The 11ß-HSD enzyme was first discovered by Amelung and his friends in 1953 (Seckl et al. 2004). This enzyme involved in conversion of inactive glucocorticoid which is cortisone (in human) and 11-dehydrocorticosterone (in rats) to active glucocorticoid which is cortisol (in human) and corticosterone (in rats) (Cooper \& Stewart 2009). The activity of $11 \beta-H S D$ enzyme in cells and tissues was first described by Monder and White in 1993 (Seckl et al. 2004). There is activity of this enzyme in the liver and it is involved in conversion of cortisol to cortisone by $11 \beta-(\mathrm{DH})$ as well as conversion of cortisone to 


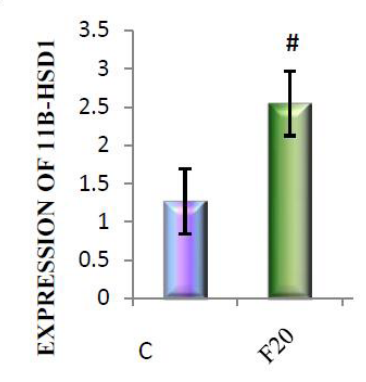

A

GROUPS

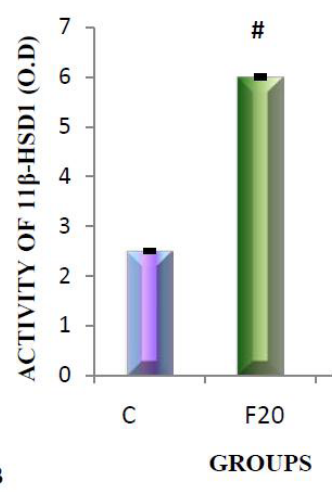

Figure 2: The graph bar of expression of $11 \beta-H S D 1$ enzyme $(A)$ and the activity of $11 \beta-H S D 1$ enzyme (B) showed statistically significant difference between F20 compared to C. \# significant compared to $\mathrm{C}, \mathrm{p}<0.05$.

cortisol by $11 \beta-(\mathrm{OR})$. Thus, it has been postulated that this enzyme is involved in the pathway of glucocorticoid. The excess of glucocorticoid can lead to the differentiation of the adipocytes (Hauner et al. 1987; Hauner et al. 1989). This differentiation is mediated by $11 \beta-H S D 1$ enzyme. Hence, the long term usage of glucocorticoid may cause MetS (Asensio et al. 2004; Rosmond 2005).

The expression of $11 \beta-H S D 1$ is also widely distributed in human and rodents tissues including liver (Ricketts et al. 1998; Moisan et al. 1990). Having the knowledge that this enzyme is present in the liver, prompted us to study the effect of FDW on $11 \beta-H S D 1$ in liver. Research done by Brereton et al. (2001) on expression of $11 \beta-H S D 1$ in the liver by using immunohistochemical technique has showed that the concentrations of the enzyme is highest around the central vein and reduced radially.

The present study was done using the full blown MetS rat model induced by fructose drinking water for eight weeks (Mamikutty et al. 2014). To utter surprise, the results indicated that with consumption of $20 \%$ fructose in drinking water for eight weeks had increased the expression as well as the activity of $11 \beta-H S D 1$ enzyme in the liver. The distribution of this enzyme was consistent with previous study which was highly distributed around the central vein and reduced radially (Brereton et al. 2001).

There are three mechanisms that we hypothesized for the development of MetS following consumption of fructose in drinking water. Firstly, consumption of fructose does increase the caloric intake, secondly by the increment of expression and activity of $11 \beta-H S D 1$ enzyme and lastly by the lipogenic property of fructose.

Consumption of fructose drinking water for eight weeks in male Wistar rats does increase the total caloric intake (Mamikutty et al. 2014). Hence, more calories were kept in the form of triglyceride (TG). Triglycerides are stored in the adipose tissue and act as an energy reservoir (Zhou \& Qin 
2012). The storage of TG in adipose tissue increased the deposition of adipose tissue in the abdomen and thus formed the central obesity. In obesity, the adipose tissue tends to expand (Zhou \& Qin 2012). The abdominal adipose tissue is the important component in the development of dyslipidemia, hyperglycemia and hypertension (Kershaw \& Flier 2004). Hypertriglyceridaemia causes reduced insulin sensitivity which leads to the development of hyperglycaemia.

The abdominal adipose tissues also activate the sympathetic nervous system (SNS) and renin angiotensin (Kotsis et al. 2010) and it is able to compress the kidney (Davy \& Hall 2004). These lead to the increase of the cardiac output (CO) and further hypertension. Angiotensinogen which is formed by adipose tissue is converted to angiotensin I. The angiotensin converting enzyme converts the angiotensin I to angiotensin II. Angiotensin II is a potent vasoconstrictor as well as causes retention of sodium and water, thus resulting in hypertension.

Apart from increased calorie intake by consumption of fructose drinking water, the development of MetS might also be established through excessive expression and activity of $11 \beta-H S D 1$ enzyme in liver. Previous studies showed that differentiation of pre-adipocyte to mature adipocyte by $11 \beta-H S D 1$ enzyme resulted in the development of central obesity (Rabbitt et al. 2002). The mature adipocyte underwent hypertrophy, which leads to obesity (Yau et al. 1995; Tomlinson \& Stewart 2001). In our study, we showed that following consumption of FDW resulted in hypertrophy of central adipocytes in obese Wistar rats (Mamikutty et al. 2014). Excessive fat will initially accumulate in adipose tissue, followed by the deposition in ectopic organs such as liver and heart (Britton \& Fox 2011). Thus, it may lead to the complication of MetS which include non-alcoholic fatty liver disease (NAFLD). This condition can deteriorate further to liver cirrhosis and liver carcinoma. Consumption of FDW $20 \%$ in male Wistar rat has proven to cause NAFLD stage 1 (Mamikutty et al. 2015).

In the development of dyslipidemia, the conversion of 11-dehydrocorticosterone to corticosterone induces the process of lipogenesis (Cooper \& Stewart 2009). Thus, more lipids are formed and increasing the triglyceride (TG) level, thereby leading to hypertriglyceridemia. The $11 \beta-H S D 1$ enzyme also plays a role in the development of diabetes mellitus and insulin resistance (Andrew \& Walker 1999). The conversion of 11-dehydrocorticosterone to corticosterone by $11 \beta-$ HSD1 enzyme resulted in gluconeogenesis hence causing hyperglycemia. This is consistent with our previous result that proved consumption of FDW20\% for eight weeks leads to hyperglycemia in Wistar rats (Mamikutty et al. 2014).

\section{CONCLUSION}

In summary, we observed an increase in the expression and activity following FDW consumption suggesting the involvement of $11 \beta-H S D 1$ enzyme in the possible mechanism of development of 
MetS in male Wistar rat. The limitation in our study was the lack of details in the molecular level concerning the $11 \beta-H S D 1$ enzyme related with obesity and metabolic syndrome. Further study is required to investigate at the molecular level to further explain the detailed pathway involved in this MetS rat model.

\section{ACKNOWLEDGEMENT}

This research was supported by Universiti Kebangsaan Malaysia research grant FF-429-2012 and UKMDLP-2011-065. The authors gratefully acknowledge the staff of Department of Anatomy, Faculty of Medicine, Universiti Kebangsaan Malaysia, Kuala Lumpur. We also thank Professor Dr. Srijit Das for the technical help.

\section{REFERENCES}

Abdulla, M.H., Sattar, M.A., Abdullah, N.A., Hye Khan, M.A., Anand Swarup, K.R., Johns, E.J. 2011. The contribution of adrenoreceptor subtype in the renal vasculature of fructose-fed Sprague-Dawley rats. European J Nutr 50(4): 251-60.

Ahmad, F., Soelaiman, I.N., Ramli, E.S., Hooi, T.M., Suhaimi, F.H. 2011. Histomorphometry changes in the perirenal adipocytes of adrenalectomized rats treated with dexamethasone. Clinics (Sao Paolo) 66(5): 849-53.

Andrews, R.C., Walker, B.R. 1999. Glucocorticoids and insulin resistance: old hormones, new targets. Clin Sci (Lond) 96(5): 513-23.

Asensio, C., Muzzin, P., Rohner-Jeanrenaud, F. 2004. Role of glucocorticoids in the physiopathologyof excessive fat deposition and insulin resistance. Int J Obes Relat Metab Disord 28 (Suppl 4): S4552.

Bellemare, V., Labrie, F., Luu-The, V. 2006. The Isolation and characterization of a cDNA encoding mouse 3alpha-hydroxysteroid dehydrogenase: an androgen-inactivating enzyme selectively expressed in female tissues. J Steroid Biochem Mol Biol 98(1): 18-24.

Britton, K.A., Fox, C.S. 2011. Ectopic fat depots and cardiovascular disease. Circulation 124(24): e837-e841.

Bujalska, I.J., Kumar, S., Stewart, P.M. 1997. Does central obesity reflect "Cushing's disease of the omentum"? Lancet 349(9060): 1210-73.

Brereton, P.S., van Driel, R.R., Suhaimi, F.B.,, Koyama, K., Dilley, R., Krozowski, Z. 2001. Light and electron microscopy localization of the 11betahydroxysteroid dehydrogenase type 1 enzyme in the rat. Endocrinology 142(4): 1644-51.

Cooper, M.S., Stewart, P.M. 2009. 11ß-hydroxysteroid dehydrogenase type 1 and its role in the hypothalamus-pituitary-adrenal axis, metabolic syndrome and inflammation. J Clin Endocrinol Metab 94(12): 4645-54.

Davy, K.P., Hall, J.E. 2004. Obesity and hypertension: two epidemics or one? Am J Physiol Regul Intergr Comp Physiol 286(5): 803-83.

Draper, N., Stewart, P.M. 2005. 11ß-hydroxysteroid dehydrogenase and the pre-receptor regulation of corticosteroid hormone action. J Endocrinol 186(2): 251-71.

Elliott, S.S., Keim, N.L., Stern, J.S., Teff, K., Havel, P.J. 2002. Fructose, weight gain and the insulin resistance syndrome. Am J Clin Nutr 76(5): 91122.

Haque, T., Mandu-Hrit, M., Rauch, F., Lauzier, D., Tabrizian, M., Hamdy, R.C. 2006. Immunohistochemical localization of bone morphogenetic protein-signaling Smads during long-bone distraction osteogenesis. J Histochem Cytochem 54(4): 407-15.

Hauner, H., Schmid, P., Pfeiffer, E.F. 1987. Glucocorticoids and insulin promote the differentiation of human adipocyte precursor cells into fat cells. J Clin Endocrinol Metab 64(4): 832-35.

Hauner, H., Entenmann, G., Wabitsch, M., Gaillard, D., Ailhaud, G., Negrel, R., Pfeiffer, E.F. 1989. Promoting effect of glucocorticoids on the differentiation of human adipocyte precursorcells cultured in a chemically defined medium. J Clin Invest 84(5): 1663-70.

Hundertmark, S., Ragosch, V., Schein, B., Bühler, H., Fromm, M., Lorenz, U., Weitzel, H.K. 1993. 11-Beta-Hydroxysteroid dehydrogenase of rat lung: enzyme kinetic, oxidase-reductase ratio, electrolyte and trace element dependence. Enzyme Protein 47(2): 83-91.

Kershaw, E.E., Flier, J.S. 2004. Adipose tissue as an endocrine organ. JClin Endocrinol Metab 89(6): 2548-56.

Kim, H.Y., Okubo, T., Juneja, L.R., Yokozawa, T. 2010. The protective role of amla (Emblica officinalis Gaertn.) against fructose-induced metabolic syndrome in a rat model. $\mathrm{Br} / \mathrm{Nutr}$ 103(4): 502-12.

Kotsis, V., Stabouli, S., Papakatsika, S., Rizos, Z., Parati, G. 2010. Mechanisms of obesity-induced hypertension. Hypertens Res 33(5): 386-93. 
Mamikutty, N., Thent, Z.C., Sapri, S.R., Sahruddin, N.N., Mohd Yusof, M.R., Haji Suhaimi, F. 2014. The establishment of metabolic syndrome model by induction of fructose drinking water in male Wistar rats. Biomed Res Int 2014: 263897.

Mamikutty, N., Thent, Z.C., Haji Suhaimi, F. 2015. Fructose-Drinking Water Induced Nonalcoholic Fatty Liver Disease and Ultrastructural Alteration of Hepatocyte Mitochondria in Male Wistar Rat. Biomed Res Int 2015: 895961.

Masuzaki, H., Paterson, J., Shinyama, H., Morton, N.M., Mullins, J.J., Seckl, J.R., Flier, J.S. 2001. A transgenic model of visceral obesity and the metabolic syndrome. Science 294(5549): 2166-70.

Moisan, M.P., Seckl, J.R., Edwards, C.R. 1990. $11 ß$-hydroxysteroid dehydrogenase bioactivity and messenger RNA expression in rat forebrain: localization in hypothalamus, hippocampus and cortex. Endocrinology 127(3): 1450-5.

Morton, N.M., Seckl, J.R. 2008. 11beta-hydroxysteroid dehydrogenase type 1 and obesity. Front Horm Res 36: 146-64.

Opperman, U. 2006. Type 1 11beta-hydroxysteroid dehydrogenase as universal drug target in metabolic diseases? Endocr Metab Immune Disord Drug Targets 6(3): 259-69.

Popovici, R.M., Betzler, N.K., Krause, M.S., Luo, M., Jauckus, J., Germeyer, A., Bloethner, S., Schlotterer, A., Kumar, R., Strowitzki, T., von Wolff, M. 2006. Gene expression profiling of human endometrial-trophoblast interaction in a coculture model. Endocrinology 147(12): 566275.

Rabbitt, E.H., Lavery, G.G., Walker, E.A., Cooper, M.S., Stewart, P.M., Hewison, M. 2002. Prereceptor regulation of glucocorticoid action by 11 beta-hydroxysteroid dehydrogenase: a novel determinant of cell proliferation. FASEB J 16(1): 36-44.

Ricketts, M.L., Verhaeg, J.M., Bujalska, I., Howie, A.J., Rainey, W.E., Stewart, P.M. 1998. Immunohistological localization of type 1 $11 \beta$-hydroxysteroid dehydrogenase in human tissues. J Clin Endocrinol Metab 83(4): 1325-35.

Rosmond, R. 2005. Role of stress in the pathogenesis of the metabolic syndrome. Psychoneuroendocrinology 30(1): 1-10.

Sánchez-Lozada, L.G., Tapia, E., Jiménez, A., Bautista, P., Cristóbal, M., Nepomuceno, T., Soto, V., Avila-Casado, C., Nakagawa, T.,
Johnson, R.J., Herrera-Acosta, J., Franco, M. 2007. Fructose-indused metabolic syndrome in associated with glomerular hypertension and renal microvascular damage in rats. Am J Physiol Renal Physiol 292(1): F423-429.

Schnackenberg, C.G., Costell, M.H., Krosky, D.J., Cui, J., Wu, C.W., Hong, V.S., Harpel, M.R., Willette, R.N., Yue, T.L. 2013. Chronic inhibition of 11 $\beta$-hydroxysteroid dehydrogenase type 1 activity decreases hypertension, insulin resistance, and hypertriglyceridemia in metabolic syndrome. Biomed Res Int 2013: 427640.

Seckl, J.R., Morton, N.M., Chapman, K.E., Walker, B.R. 2004. Glucocorticoids and 11betahydroxysteroid dehydrogenase in adipose tissue. Recent Prog Horm Res 59: 359-93.

Shahraki, M.R., Harati, M., Shahraki, A.R. 2011. Prevention of high fructose-induced metabolic syndrome in male Wistar rats by aqueous extract of tamarindus indica seed. Acta Med Iran 49(5): 277-83.

Shimojo, M., Whorwood, C., Stewart, P. 1996. 11 beta-Hydroxysteroid dehydrogenase in the rat adrenal. JMol Endocrinol 17(2): 121-30.

Tomlinson, J.W., Stewart, P.M. 2001. Cortisol metabolism and the role of 11betahydroxysteroid dehydrogenase. Best Pract Res Clin Endocrinol Metab 15(1): 61-78.

Walker, B.R., Yau, J.L., Brett, L.P., Seckl, J.R., Monder, C., Williams, B.C., Edwards, C.R. 1991. 11 betahydroxysteroid dehydrogenase in vascular smooth muscle and heart: implications for cardiovascular responses to glucocorticoids. Endocrinology 129(6):3305-12.

Whorwood, C.B., Franklyn, J.A., Sheppard, M.C., Stewart, P.M. 1992. Tissue localization of 11beta-hydroxysteroid dehydrogenase and its relationship to the glucocorticoid receptor. J Steroid Biochem Mol Biol 41(1): 21-8.

Yau, J.L., Olsson, T., Morris, R.G., Meaney, M.J., Seckl, J.R. 1995. Glucocorticoids, hippocampal corticosteroid receptor gene expression and antidepressant treatment: relationship with spatial learning in young and aged rats. Neuroscience 66(3): 571-81.

Zhou, J., Qin, G. 2012. Adipocyte dysfunction and hypertension. Am J Cardiovasc Dis 2(2): 143-9.

Received: 10 November 2016

Accepted: 9 May 2017 